This work was carried out by the University of California under contract with the U.S. Offiee of Naval Research. Additional support was provided by National Science Foundation grant $G-4801$.

$$
\text { Elizabeth M. KaMpa }
$$

University of California,

Scripps Institution of Oceanography, La Jolla.

Bernard C. AbBott

University of California,

Los Angeles. March 31 .

${ }^{1}$ Kampa, E. M., Nature, 175, 996 (1955).

\section{Melatonin in Peripheral Nerve}

Melatonin is a hormone, isolated from beef pineal glands, that lightens the colour of frog melanocytes either after injection into the frog or after in vitro incubation with pieces of frog skin ${ }^{1}$. In addition, this hormone can block and reverse the darkening actions of the melanocyte-stimulating hormones and also of adrenocorticotrophic hormone. Melatonin is a 5-hydroxyindole derivative in which the hydroxy group is blocked ${ }^{2}$. Its melanocyte-lightening properties are more than ten thousand times greater than those of noradrenaline, which previously was considered to be the most potent lightening agent known ${ }^{3}$. In our early experiments melatonin could be detected only in extracts from pineal glands and not from other tissues. With improvement in extraction techniques we have been able to identify the presence of a lightening agent that is most likely melatonin in peripheral nerves of man, monkey and cow. A detailed mapping of the location of melatonin in the nervous system has not been completed.

Sciatic nerves from human beings were collected at autopsy and stored at $-10^{\circ} \mathrm{C}$. until a total of $65 \mathrm{gm}$. of tissue was obtained. This material was lyophilized to give $28 \mathrm{gm}$. of dry tissue. The latter was cut into small pieces and defatted with petroleum ether in a Soxhlet extractor. $10 \mathrm{gm}$. of dry, defatted. nervous tissue was obtained which was pulverized to a powder in a Waring blendor. The powder was mixed with $100 \mathrm{ml}$. water in the blendor, and the mixture was centrifuged at $15,000 \mathrm{~g}$ for $30 \mathrm{~min}$. The supernatant fluid was filtered and the residue extracted with $100 \mathrm{ml}$. water and centrifuged again. The combined filtrates were extracted twice with equal volumes of ethyl acetate. The ethyl acetate layer was evaporated to dryness in vacuo. The residue was dissolved in a mixture of $10 \mathrm{ml}$. of each layer of solution used for counter-current distribution. This solvent system was made by equilibrating 2 parts of water with 1 part of ethylacetate and I part of $n$-heptane. All solvents were redistilled prior to use. The dissolved residue was subjected to 29 transfers in a counter-current distribution apparatus. The contents of the tubes were pooled into four groups : 0-7, 8-14, 15-22 and 23-29. From each pooled group the organic phase plus the upper phase obtained by re-extraction of the water layer with an equal volume of ethyl acetate were combined and evaporated to dryness in vacuo. The four residues, each dissolved in $2 \mathrm{ml}$. ethanol, were assayed for their ability to lighten isolated pieces of frog skin. Activity was found only in material from tubes 8-14. Similar results were obtained from extracts made in the same way using collections of sciatic, femoral and brachial nerves of monkevs and spinal nerve roots of cows.
Purified melatonin, when subjected to a similar counter-current distribution, is found in greatest concentration in tube 11 ; and there is the expected decrease in concentration as one moves in either direction away from the peak tube. Tubes 8-14 contain nearly all the melatonin. The active material from tubes 8-14 of the counter-current distribution of human nerve was put through the counter-current machine again. Tube 11 contained the highest concentration of the lightening agent. This location coincides with that expected from distributing melatonin. There was not enough material in tubes 8-14 to test with Ehrlich's reagent or to obtain a fluorescence curve. Other known lightening agents, for example, noradrenaline, adrenaline, acetylcholine, serotonin, triiodothyronine and hydrocortisone, are eliminated by the extraction procedures.

Since the solubility and biological properties of the agent obtained from nerves of human beings, monkeys and cows are identical with those of melatonin and different from those of other known lightening agents, it is likely that the active principle is melatonin.

The function of this powerful melanocyte-lightening agent in peripheral nerve is not known. It may play a part in the transmission of nerve impulses and in the pathogenesis of vitiligo and malignant melanomas.

Aaron B. Lerner

JAMES D. CASE

WATARU MORI

Margaret R. Wright

Section of Dermatology,

Department of Medicine,

Yale University School of Medieine,

New Haven, Connectieut. March 25.

${ }^{1}$ Lerner, A. B., Case, J. D., Takahashi, Y., Lee, T. H., and Mori, W., J. Amer Chem. Soc., 80, 2587 (1958).

${ }^{2}$ Case, J. D., and Lerner, A. B. (to be published).

${ }^{3}$ Lerner, A. B., and Case, J. D., J. Invest. Dermatol., 32, 211 (1959).

\section{Effect of Enzymes on Mechanical Properties of Tissues}

WHILE investigating the effect of extending forces on the excised uterine cervix of the rat $^{1}$ we found that at the end of pregnancy the tissue showed prolonged extension at constant rate under low loads, behaving as if the collagenous framework in it was not continuous, as it is in the majority of tissues, but was one in which the ultimate links were viscous. In the course of investigating this viscous state we tried the effect of soaking the tissue in solutions containing trypsin. This was found to increase dramatically the rate of extension under constant load. Similar results were obtained from rings of skin cut from around the body-wall of newly born rats. Chymotrypsin was also tried on these and found to have the same effect as trypsin.

After excision, tissues were left overnight in the refrigerator $\left(5^{\circ} \mathrm{C}\right.$.) in the enzyme solutions (crystalline Armour preparations, trypsin $0.5 \mathrm{mgm} . / \mathrm{ml}$, chymotrypsin $1.0 \mathrm{mgm} . / \mathrm{ml}$.) and incubated for $15 \mathrm{~min}$. at $37^{\circ} \mathrm{C}$. before testing. The method of using the enzymes and the concentration of trypsin were suggested to us by P. B. Medawar as suitæble for detaching epidermis without killing the cells. Tissues were stretched between two parallel steel rods (stain. less steel hypodermic needle tubing $0 \cdot 6 \mathrm{~mm}$. diam.). In the case of the cervix, one rod went through each canal, while the skin formed a belt around both rods. 